\title{
Influence of moisture content on the mechanical properties of Guadua Culms
}

\section{Influencia del contenido de humedad en las propiedades mecánicas de la Caña de Guadua}

\author{
DOI: http://dx.doi.org/10.17981/ingecuc.15.1.2019.09
}

Research Article. Reception Date: 10/07/2018, Acceptance date::12/02/2019.

\author{
Martha L. Sánchez \\ Universidad Militar Nueva Granada Bogotá, (Colombia). \\ martha.sanchez@unimilitar.edu.co \\ Luz Y. Morales \\ Universidad Militar Nueva Granada Bogotá, (Colombia). \\ luz.morales@unimilitar.edu.co
}

Para citar este artículo:

M. L. Sánchez and L. Y. Morales "Influence of Moisture Content on the mechanical properties of Guadua culms," INGE CUC, vol. 15, no. 1, pp. 99-108, 2019. DOI: http://doi.org/10.17981/ingecuc.15.1.2019.09

\begin{abstract}
Introduction- Due to its earthquake behavior, the use of bamboo for structural purposes has increased in the latest decades, mainly in South American countries, in which, their employment, has been standardized in the design bases. However, for the efficient use of bamboo as a construction material, it is necessary to consider that being a natural material, volumetric variations can occur, especially when the material is subjected to changes in moisture between the saturation point of the fibers and the equilibrium moisture.
\end{abstract}

Objectives- The objective of this paper is to evaluate the influence of the moisture content on the mechanical properties of elements extracted from the bottom, middle, and top of bamboo culms.

Methodology- For the study, research is carried out with a quantitative approach. The experimental characterization was focused on the determination of compression, bending, and shear strength, according to the recommendations of the Colombian Technical Standards.

Results- Results allow verifying that bamboo elements are susceptible to vary their strength and stiffness depending on the equilibrium moisture of the region to be considered in the structural design.

Conclusions- The influence of the moisture content on the mechanical properties of elements extracted from the bottom, middle, and top of bamboo culms was evaluated. The experimental characterization was focused on the determination of compression, bending, and shear strength. From the results, it is possible to verify that an increase in the moisture content reduces the mechanical strength of the material. The decrease in the values of maximum stress is more significant for moisture values between $12 \%$ and the saturation point of the fibers and is accompanied by important dimensional changes that impair the mechanical performance of the material. The results show that above the point of saturation of the fibers the mechanical behavior of the culms is not modified.

Keywords: Bamboo; moisture content; compression; shear; bending

\section{Resumen}

Introducción- debido a su comportamiento sismo resistente, el uso del bambú con fines estructurales se ha incrementado en las últimas décadas, principalmente en los países de América del Sur; en los cuales, su empleo, se ha estandarizado en las bases para el diseño estructural. Sin embargo, para el uso eficiente del bambú como material de construcción, es necesario considerar que al ser un material natural, pueden ocurrir variaciones volumétricas, especialmente cuando el material es sometido a cambios en el nivel de humedad entre el punto de saturación de las fibras y el punto de equilibrio de humedad.

Objetivos- El objetivo de este trabajo es evaluar la influencia del nivel de humedad sobre las propiedades mecánicas de los elementos extraídos de las cañas de bambú de la parte inferior, media y superior, con edades comprendidas entre 4 a 6 años, después de inmunizados con una solución de ácido bórico.

Metodología- Para el desarrollo del estudio, se llevó a cabo una investigación con un enfoque cuantitativo. La caracterización experimental se centró en la determinación de la compresión, la flexión y la resistencia al corte, de acuerdo con las recomendaciones de las Normas Técnicas de Colombia (NTC).

Resultados- Los resultados permiten evidenciar que los elementos de bambú son susceptibles de variar su resistencia y rigidez dependiendo de la humedad de equilibrio de la región a considerar en el diseño estructural.

Conclusiones- Se evaluó la influencia del nivel de humedad en las propiedades mecánicas de los elementos extraídos de los culmos de bambú de la parte inferior, media y superior. A partir de los resultados, es posible verificar que un incremento en el nivel de humedad reduce la resistencia mecánica del material. La disminución en los valores de tensión máxima es más significativa para los valores de humedad comprendidos entre el $12 \%$ y el punto de saturación de las fibras, y se acompaña de importantes cambios dimensionales que impiden el rendimiento mecánico del material. Los resultados muestran que, por encima del punto de saturación de las fibras, no se modifica el comportamiento mecánico de las cañas.

Palabras clave- Bambú; contenido de humedad; compresión; cortante; flexión 


\section{INTRODUCTION}

Currently, the use of non-conventional materials has gained importance in several areas of civil engineering. The strength of bamboo culms, their low weight, and their hollow cylindrical structure make this type of material a feasible option for the elaboration of structural elements that are subjected to the action of axial and flexural loads during their service life [1]. However, it has been found that as a lignocellulosic material, both the physical and mechanical properties of the material can be noticeably affected when the material is subjected to humidity conditions for prolonged periods [2], [3].

In recent years, the study of the effect of the variations of moisture content on the mechanical performance of structures made from lignocellulosic materials has been reported in the specialized literature [4]-[14]. Mvondo et al. [15], analyzed the effect of moisture content on the tensile and flexural strength of three species of tropical wood: Milicia excelsa, Nauclea diderrichii and Erythrophleum suaveolens, varying the moisture content between $10 \%$ and $30 \%$. This paper not only demonstrates a loss of mechanical strength with increasing moisture content but also establishes the effect of moisture on the main functional groups present in the wood.

According to Okhio et al. [1], analysis of the influence of the moisture content on bamboo elements may become more complex than for wood elements. This is because in the culms the humidity can vary not only throughout the culm length but also throughout its cross-section [1]. Research results on the physical and mechanical properties of bamboo culms have focused on evaluating the effect of moisture content on the specific weight, dimensional stability, and compressive strength of bamboo culms of the Dendrocalamus giganteus species, analyzing the age of harvest and the conditions of growth (altitude above sea level) [16].

It has been shown that it is possible to degrade the mechanical properties of structural elements when they are subjected to wet conditions for extended periods of time [16], [17]. Xu et al. [18], analyzed the behavior of bamboo culms after their immersion in water for 1 and 7 days, thus simulating the behavior of the material when subjected to the effect of rainy periods. This study showed that with exposure to heavy rains, bamboo elements not only lose mechanical strength but also go from having a fragile behavior to very ductile behavior. On the other hand, Jakovljevic et al. [19], analyzed the influence of the moisture content on the mechanical properties (tensile, compression, and static bending) of bamboos of the species Pseudosasa Amabilis and Pleioblastus Amarus. The study was based on analyzing the performance of the material after being in a wet chamber for three weeks. The results confirmed that regardless of the type of stress, mechanical strength is significantly reduced when the material has a moisture content of about $60 \%$.

In Colombia, experimental studies have been carried out during the last decade. In these investigations, the influence of the moisture content on the strength of elements of Guadua culms has been verified [20], [21], [22]. According to Gutiérrez and Takeuchi [20], bamboo elements of Guadua angustifolia Kunth do not exhibit a significant reduction in the tensile strength parallel to the fiber within the range of humidity in which the material is used for structural purposes [20]. However, results presented by Dumar (2014) demonstrate that both the flexural strength and the modulus of elasticity decrease linearly for every $0.01 \%$ that the moisture content in the Guadua angustifolia Kunth increases, when the material is below its proportionality limit [23]. Based on the literature consulted, the present paper presents an experimental methodology for the evaluation of the effect of moisture content on the tensile, compressive and flexural strength of specimens extracted from Guadua angustifolia Kunth bamboo culms, analyzing its influence in the determination of the maximum strength to be used in the earthquake-resistant design of bamboo structures.

\section{Materials and Methods}

Guadua angustifolia Kunth species were selected, with an average age of 4 years, immunized by injection of a solution of pentaborate and boric acid [21]. The material used comes from the municipality of Calarcá, Quindío. From each of the culm regions, bottom (B), middle (M) and, top (T) sections were cut and labeled as test pieces according to specifications of the Colombian technical standard NTC 5525 [24].

For the variation of moisture content, an immersion method was used. The specimens were previously dried in an oven at a temperature of $102^{\circ} \mathrm{C}$ for 24 hours or to constant mass condition. They were then submerged in a container with water at room temperature. The immersion time was established by previous tests in which the time was determined to achieve the desired variations in the value of the moisture content.

The determination of the moisture content was performed immediately after completion of the mechanical characterization tests, establishing the mass loss for each specimen, expressed as a percentage of the oven-dry mass, using Equation "(1)":

$$
C H=\frac{w_{h}-w_{s}}{w_{s}} 100
$$

where

$\mathrm{CH}$ is the moisture content, in \%

$w_{h}$ is the mass of the wet specimen, in $g$

$w_{s} \quad$ is the mass of the oven-dried specimen, in $g$ 
For the determination of the basic density, prismatic specimens were prepared, with an average width of $25 \mathrm{~mm}$, height of $25 \mathrm{~mm}$, and thickness equal to the thickness of the culm wall. The density (mass, ovendried, per unit of wet or green volume) of each sample was obtained using Equation "(2)". The volume of the samples in wet or green condition, was determined using the dimensions of the sample according to the procedure recommended in the NTC 5525 [24].

$$
D B=\frac{w_{s}}{V_{v}}
$$

where

$D B \quad$ is the basic density, in $\mathrm{g} / \mathrm{cm}^{3}$

$w s$ is the mass of the oven-dried specimen, in $g$

$V v \quad$ is the wet (green) volume of the specimen, in $\mathrm{cm}^{3}$.

To determine the FSP, the method proposed by Fuentes (2000) was applied. In this method, the relationship between the volumetric contraction and the basic density was established [25].

The volumetric contraction index from the initial wet condition to the final dry condition and the saturation point of the fibers was calculated according to Equations “(3)”, and “(4)”:

$$
\begin{array}{cc}
I C V=\frac{V_{v}-V_{s}}{V_{v}} & 100 \\
F S P=\frac{I C V}{0.9 D B} & 100
\end{array}
$$

where

$V v \quad$ is the wet (green) volume of the specimen, in $\mathrm{cm}^{3}$.

$V s \quad$ is the dry volume of the specimen, in $\mathrm{cm}^{3}$.

$I C V$ is the rate of volumetric shrinkage, in \%

FSP is the saturation point of fibers, in \%

Table 1. Average dimensions of Specimens used in COMPREssion TEST

\begin{tabular}{|c|c|c|c|}
\hline Specimens & $\begin{array}{c}\text { External } \\
\text { diameter }(\mathrm{mm})\end{array}$ & $\begin{array}{c}\text { Thickness } \\
(\mathrm{mm})\end{array}$ & Height $(\mathrm{mm})$ \\
\hline $\begin{array}{c}\text { Top without } \\
\text { node }\end{array}$ & $93.60 \pm 0.28$ & $13.78 \pm 0.72$ & $101.08 \pm 0.66$ \\
\hline $\begin{array}{c}\text { Top with } \\
\text { node }\end{array}$ & $97.12 \pm 3.7$ & $9.73 \pm 2.09$ & $101.09 \pm 2.82$ \\
\hline $\begin{array}{c}\text { Middle } \\
\text { without } \\
\text { node }\end{array}$ & $106.59 \pm 2.43$ & $12.12 \pm 0.9$ & $104.53 \pm 8.81$ \\
\hline $\begin{array}{c}\text { Middle with } \\
\text { node }\end{array}$ & $110.87 \pm 0.73$ & $13.10 \pm 0.83$ & $111.86 \pm 1.21$ \\
\hline $\begin{array}{c}\text { Bottom } \\
\text { without } \\
\text { node }\end{array}$ & $134.35 \pm 1.13$ & $14.49 \pm 0.27$ & $128.74 \pm 1.57$ \\
\hline $\begin{array}{c}\text { Bottom } \\
\text { with node }\end{array}$ & $138.04 \pm 0.04$ & $19.95 \pm 1.05$ & $136.89 \pm 2.71$ \\
\hline
\end{tabular}

Source: Authors.
For compression tests, 210 samples of equal length and diameter were prepared. To evaluate the effect of the culm region on strength, 70 specimens were prepared from each of the regions. The geometric properties were measured and are shown in Table 1.

The compression test was performed according the specifications of NTC 5525 [24]. The load was applied at a speed of $0.01 \mathrm{~mm} / \mathrm{s}$, until failure occurred. The maximum compression stress was determined according to Equation “(5)”:

$$
\sigma=\frac{F}{A}
$$

where

$\sigma \quad$ is the compression stress, in $M P a$

$F \quad$ is the maximum compression load, in $N$.

$A$ is the net cross-sectional area, in $\mathrm{mm}^{2}$.

For the shear tests, 210 specimens of equal length and diameter $(L=D)$ were prepared. The geometric properties are shown in Table 2 .

Table 2. Average dimensions of Specimens Used In Shear test

\begin{tabular}{|c|c|c|}
\hline Specimens & Thickness $(\mathrm{mm})$ & Height $(\mathrm{mm})$ \\
\hline Top without node & $9.92 \pm 0.33$ & $87.94 \pm 0.11$ \\
\hline Top with node & $10.22 \pm 0.26$ & $100.84 \pm 0.15$ \\
\hline Middle without node & $13.56 \pm 0.41$ & $105.83 \pm 0.17$ \\
\hline Middle with node & $13.45 \pm 0.28$ & $105.76 \pm 0.13$ \\
\hline Bottom without node & $23.19 \pm 0.39$ & $136.40 \pm 0.09$ \\
\hline Bottom with node & $23.39 \pm 0.24$ & $136.21 \pm 0.11$ \\
\hline
\end{tabular}

Source: Authors.

For the determination of the maximum strength, a universal test machine was used, in which the specimen was supported at the lower end on two quarters of its surface, applying the load at the upper end on the two quarter parts that were not supported. This way of supporting and applying the load to the specimen produces four cutting areas (see Fig. 1). For the test, the load was applied at a speed of 0.01 $\mathrm{mm} / \mathrm{s}$. This test allowed the determination of the maximum load at which the specimen failed, as well as the number of areas that failed. The maximum parallel shear strength was determined according to Equation "(6)":

$$
\tau=\frac{F}{\sum(t * L)}
$$

where

$\tau \quad$ is the shear strength, in $\mathrm{MPa}$

$F \quad$ is the applied load, in $N$

$t \quad$ is the thickness of specimen, in $\mathrm{mm}$

$L \quad$ is the height of the specimen, in $\mathrm{mm}$ 


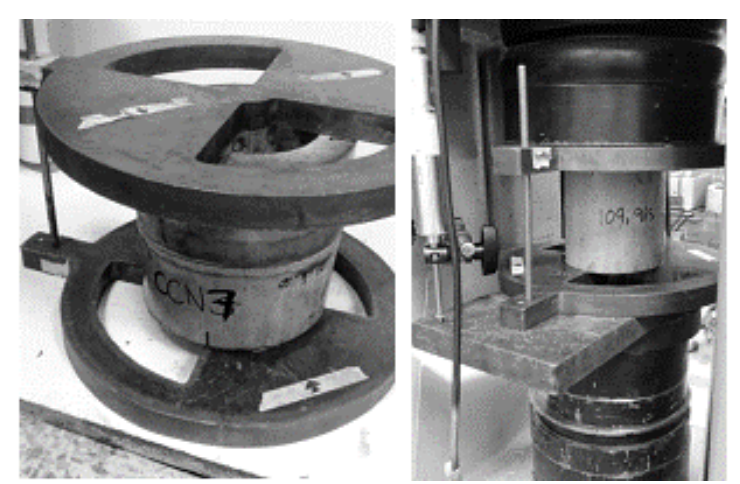

Fig. 1. Shear tests. Source: Authors.

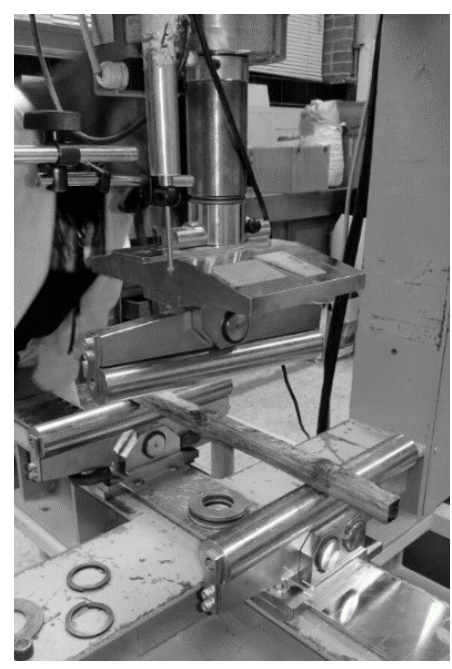

Fig. 2. Static bending tests. Source. Authors.

For the determination of the modulus of rupture (MOR), a three-point bending test was performed (See Fig. 2). For the test, 150 rectangular beams of $500 \mathrm{~mm}$ in length and a square section according to the thickness of the culm region were cut. The beams were selected in order to guarantee the existence of a node in the center of the same (point of application of load) and their supports. The load was applied at a speed of $0.01 \mathrm{~mm} / \mathrm{s}$. The physical properties are shown in Table 3. Displacements were measured using a linear variable displacement transducer (LVDT). The rupture modulus (MOR) and the flexural modulus (MOE) were calculated using Equations "(7)", and “(8)":

$$
\begin{aligned}
& M O R=\frac{3 F L}{2 b d^{2}} \\
& M O E=\frac{F L^{2}}{4 b \delta d^{3}}
\end{aligned}
$$

$$
\begin{array}{ll}
\text { where } \\
F & \text { is the applied load, in } N \\
d & \text { is the thickness of specimen, in } \mathrm{mm} \\
L & \text { is the distance between supports, in } \mathrm{mm} \\
b & \text { is the width of the beam, in mm } \\
\delta & \text { is the displacement at the middle of span, } \\
& \text { in mm }
\end{array}
$$

Table 3. Average dimensions of Specimens used in Bending test

\begin{tabular}{|c|c|c|}
\hline Specimens & Thickness $(\mathrm{mm})$ & Width $(\mathrm{mm})$ \\
\hline Top & $9.85 \pm 0.45$ & $9.62 \pm 0.63$ \\
\hline Middle & $10.38 \pm 0.25$ & $10.49 \pm 0.39$ \\
\hline Bottom & $20.95 \pm 0.37$ & $21.30 \pm 0.09$ \\
\hline \multicolumn{3}{|c|}{ Source: Authors. }
\end{tabular}

\section{Results And Discussions}

The volumetric contraction index and the basic density of specimens extracted from the Guadua culms were determined according to the specifications of NTC 5525 [24]. From the results, it is possible to estimate the saturation point of the fibers (FSP) of the material. The results are shown in Table 4.

Table 4. Saturation Point of Fibers

\begin{tabular}{|c|c|c|c|}
\hline Region & ICV (\%) & DB $\left(\mathrm{g} / \mathrm{cm}^{3}\right)$ & FSP (\%) \\
\hline Top & $10.43 \pm 1.36$ & $0.57 \pm 0.05$ & $21.26 \pm 1.09$ \\
\hline Middle & $11.74 \pm 0.78$ & $0.58 \pm 0.02$ & $22.42 \pm 1.14$ \\
\hline Bottom & $13.59 \pm 0.83$ & $0.61 \pm 0.08$ & $24.78 \pm 0.83$ \\
\hline
\end{tabular}

Source: Authors.

From the results presented in Table 4, it is possible to see that elements extracted from the bottom of Guadua culms have a higher volumetric contraction index than elements extracted from the middle and top regions (for moisture content below the saturation point of the fibers). Similar results were obtained by Gutierrez et.al [26], and may be associated with the graded functionality of the material [1], [27], [28]. The higher content of parenchymal tissue present in the base of the culms promotes a rapid absorption of water in the material, affecting the performance of material when it is subjected to humid conditions.

In order to analyze the influence of the moisture content on the strength to parallel compression of Guadua culms, graphs of maximum stress were drawn as a function of the moisture content. The results are shown in Figs. 3-8. Average values of representative points obtained during the test are shown in Tables 5, 6, and 7 . 


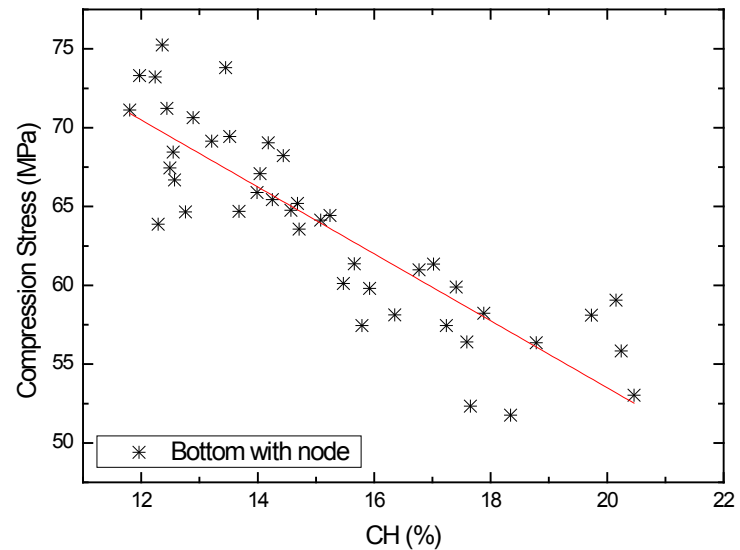

Fig. 3. Variation of compression stress with moisture content in the bottom with node. Source: Authors.

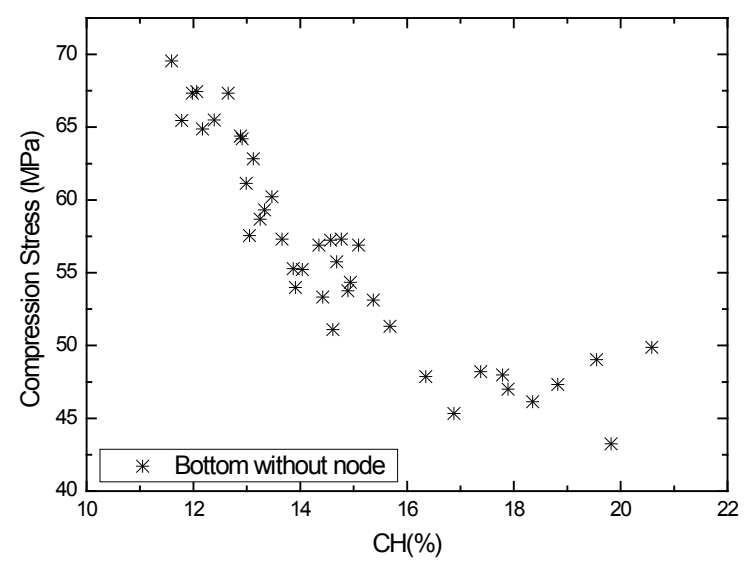

Fig. 4. Variation of compression stress with moisture content in the bottom without node. Source: Authors.

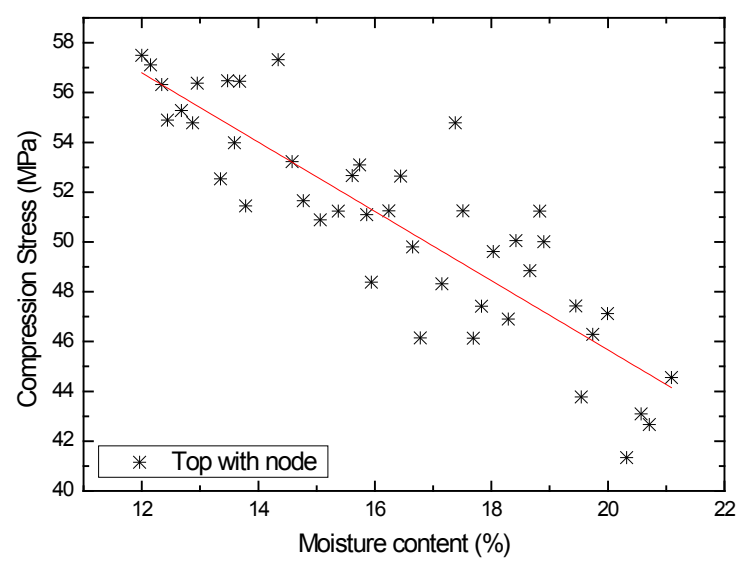

Fig. 5. Variation of compression stress with moisture content in the top with node. Source: Authors.

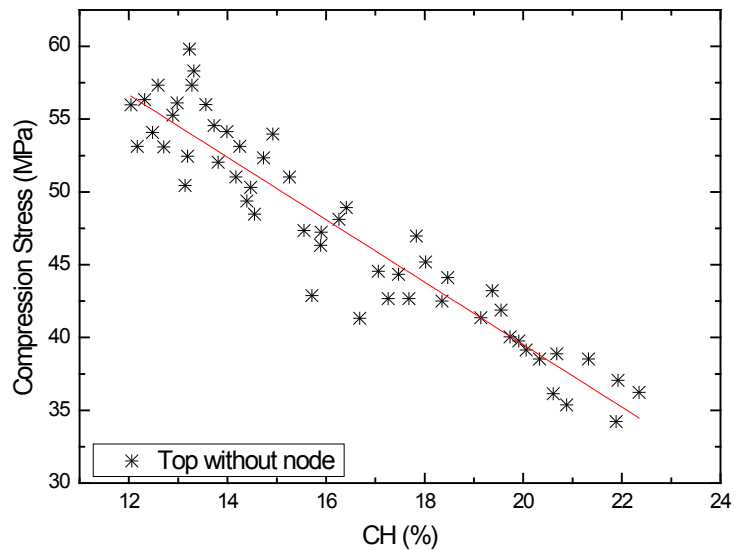

Fig. 6. Variation of compression stress with moisture content in the top without node. Source: Authors.

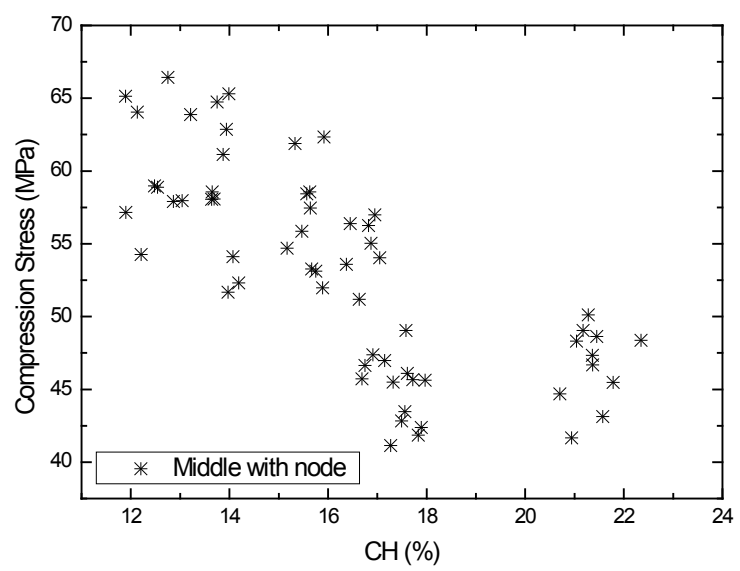

Fig. 7. Variation of compression stress with moisture content in the middle with node. Source: Authors.

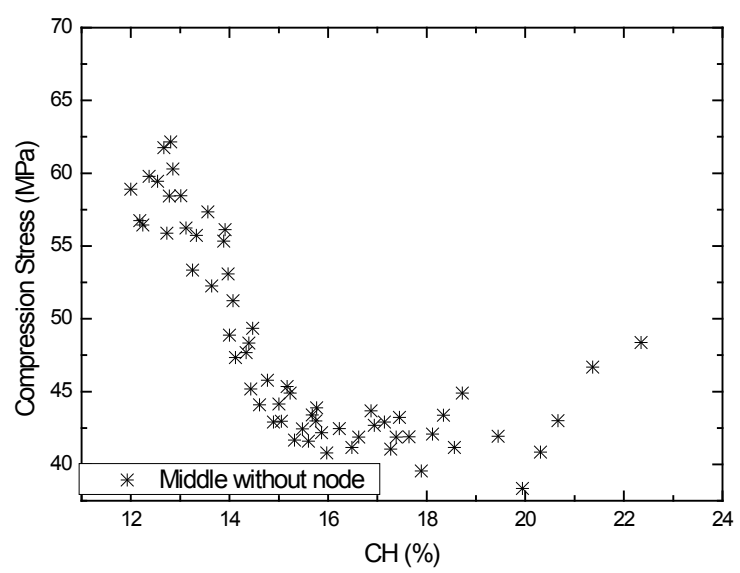

Fig. 8. Variation of compression stress with moisture content in the middle without node. Source: Authors. 


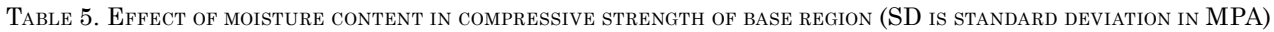

\begin{tabular}{|c|c|c|c|c|c|}
\hline \multirow{2}{*}{$\mathrm{CH}(\%)$} & \multicolumn{2}{|c|}{ With node } & \multirow{2}{*}{$\mathrm{CH}(\%)$} & \multicolumn{2}{|c|}{ Without node } \\
\cline { 2 - 3 } \cline { 6 - 6 } & $\sigma(\mathrm{MPa})$ & $\mathrm{SD}(\mathrm{MPa})$ & & $\sigma(\mathrm{MPa}$ & $\mathrm{SD}(\mathrm{MPa})$ \\
\hline $12.00-13.30$ & 69.86 & 8.38 & $11.60-12.50$ & 65.07 & 5.86 \\
\hline $13.50-14.00$ & 67.32 & 10.77 & $12.80-13.60$ & 60.68 & 6.68 \\
\hline $14.01-15.55$ & 66.61 & 6.00 & $13.80-15.40$ & 55.40 & 4.43 \\
\hline $16.60-19.00$ & 62.63 & 8.77 & $16.00-17.10$ & 53.41 & 4.27 \\
\hline $19.10-21.30$ & 56.23 & 2.81 & $19.00-21.00$ & 50.20 & 6.04 \\
\hline $21.50-22.10$ & 52.29 & 3.66 & $21.20-23.50$ & 46.41 & 4.18 \\
\hline
\end{tabular}

Source: Authors.

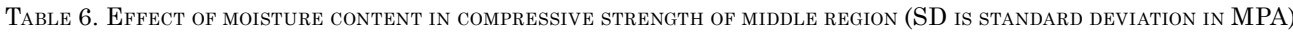

\begin{tabular}{|c|c|c|c|c|c|}
\hline \multirow{2}{*}{ CH (\%) } & \multicolumn{2}{|c|}{ With node } & \multirow{2}{*}{ CH $(\%)$} & \multicolumn{2}{|c|}{ Without node } \\
\cline { 2 - 3 } & $\sigma(\mathrm{MPa})$ & $\mathrm{SD}(\mathrm{MPa})$ & & $\sigma(\mathrm{MPa}$ & $\mathrm{SD}(\mathrm{MPa})$ \\
\hline $12.00-13.00$ & 60.45 & 7.86 & $11.80-12.50$ & 58.91 & 5.89 \\
\hline $13.01-15.00$ & 58.54 & 5.27 & $13.00-15.00$ & 54.96 & 7.14 \\
\hline $15.01-16.25$ & 56.70 & 9.07 & $15.10-16.00$ & 43.03 & 6.89 \\
\hline $16.50-17.00$ & 52.06 & 4.16 & $16.50-18.75$ & 42.41 & 3.39 \\
\hline $17.01-18.00$ & 48.97 & 6.37 & $20.50-22.00$ & 42.10 & 4.63 \\
\hline $20.00-22.65$ & 46.69 & 8.40 & $22.40-24.00$ & 40.01 & 4.80 \\
\hline
\end{tabular}

Source: Authors

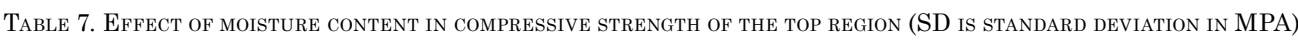

\begin{tabular}{|c|c|c|c|c|c|}
\hline \multirow{2}{*}{$\mathrm{CH}(\%)$} & \multicolumn{2}{|c|}{ With node } & \multirow{2}{*}{$\mathrm{CH}(\%)$} & \multicolumn{2}{c|}{ Without node } \\
\cline { 6 - 6 } & $\sigma(\mathrm{MPa})$ & $\mathrm{SD}(\mathrm{MPa})$ & & $\sigma(\mathrm{MPa}$ & $\mathrm{SD}(\mathrm{MPa})$ \\
\hline $12.10-13.00$ & 56.59 & 8.49 & $11.10-13.00$ & 55.84 & 2.79 \\
\hline $15.09-16.99$ & 56.54 & 7.35 & $13.20-15.00$ & 53.40 & 3.74 \\
\hline $17.70-18.50$ & 50.05 & 5.51 & $15.10-16.20$ & 46.42 & 5.11 \\
\hline $18.51-19.60$ & 47.79 & 4.30 & $17.00-19.00$ & 44.98 & 4.05 \\
\hline $20.90-22.50$ & 45.51 & 2.73 & $21.31-23.00$ & 35.74 & 2.14 \\
\hline $22.70-24.50$ & 42.89 & 3.43 & $24.12-25.89$ & 35.12 & 2.80 \\
\hline
\end{tabular}

Source: Authors

From the results shown in Figs. 3-8, it is possible to observe that when humidity increases between 12 and $23 \%$, a reduction in the values of compressive strength for the three regions of the world analyzed in this work can occur. This reduction in compressive strength is more significant for intermodal regions (30-35\%) and can be associated with the capacity of absorption of the bamboo parenchyma cells [29].

On analyzing the results shown in Tables $6-8$, it is possible to notice a reduction of between 23 and $30 \%$ in the value of the compressive strength in the direction parallel to the fibers when the moisture content increases between $12 \%$ and the point of saturation of the fibers, for base specimens. Similarly, Jiang et al. [30], showed that a reduction approximately of $42 \%$ in the compressive strength of bamboo specimens of the species is possible when the moisture content varies between $12 \%$ and $22 \%$ and allow demonstrating the degradation that occurs in the mechanical strength of the material with an increase in their moisture content.

To analyze the influence of the moisture content on the shear behavior of bamboo, cylindrical specimens were tested. The results are shown in Figs. 9-14. 


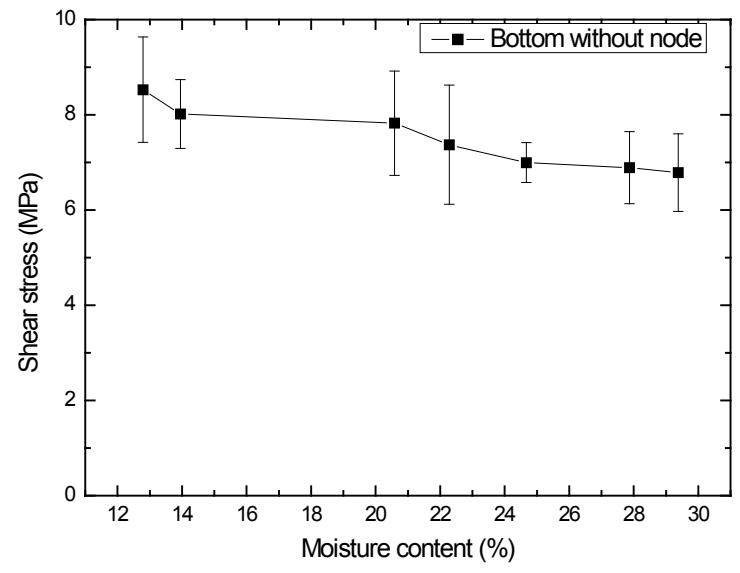

Fig. 9. Variation of shear stress with moisture content in the bottom without node. Error bars represent the standard deviation. Source: Authors.

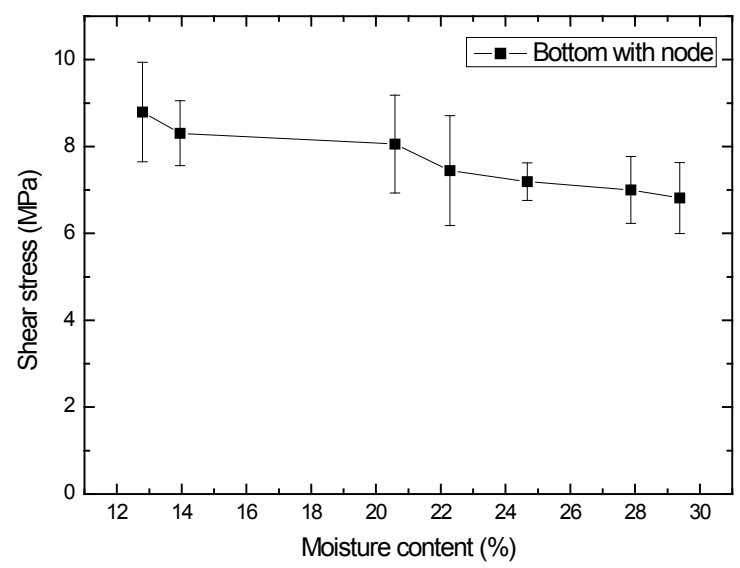

Fig. 10. Variation of shear stress with moisture content in the bottom with node. Error bars represent the standard deviation. Source: Authors.

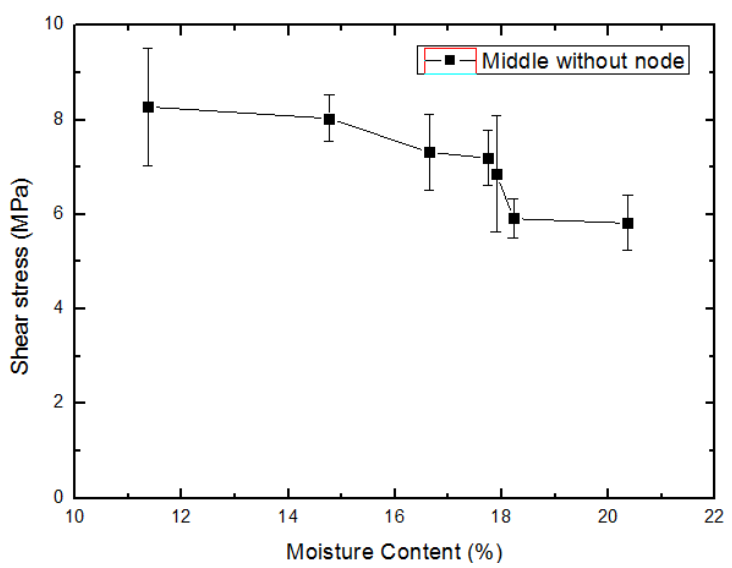

Fig. 11. Variation of shear stress with moisture content in the middle without node. Error bars represent the standard deviation Source: Authors.

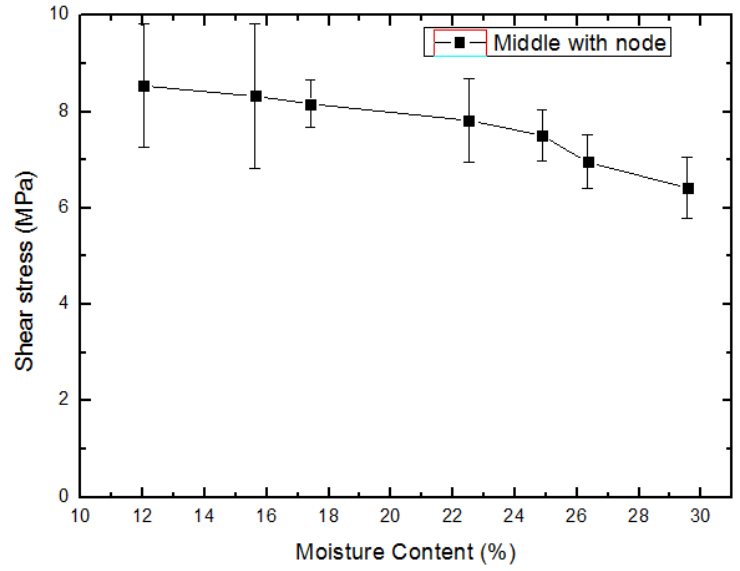

Fig. 12. Variation of shear stress with moisture content in the middle with node. Error bars represent the standard deviation. Source: Authors.

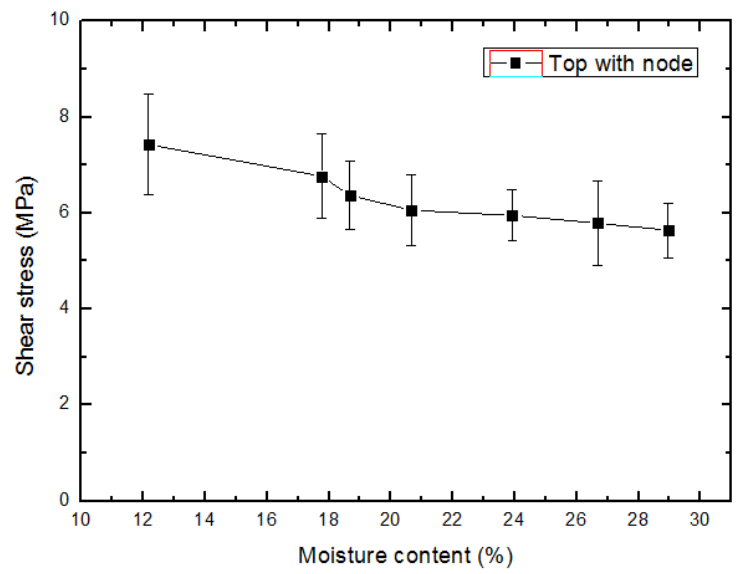

Fig. 13. Variation of shear stress with moisture content in the top with node. Error bars represent the standard deviation Source: Authors.

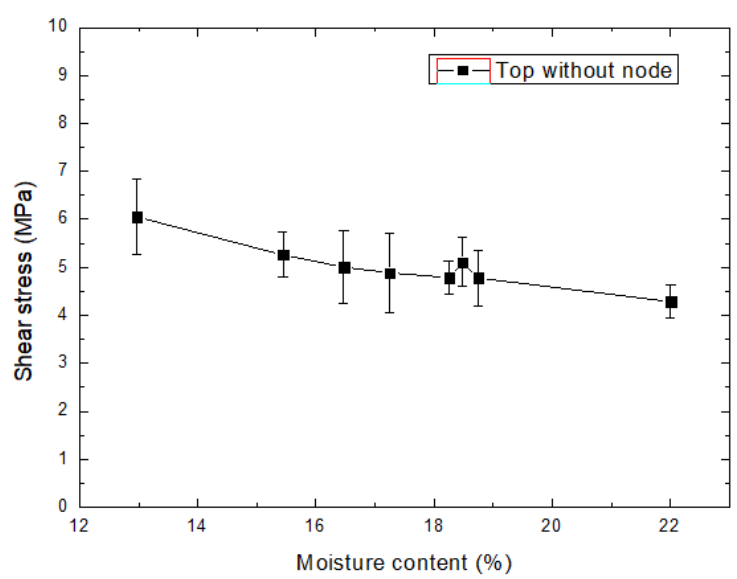

Fig. 14. Variation of shear stress with moisture content in the top without node. Error bars represent the standard deviation. Source: Authors. 
From the results presented in Fig.9-14, it is possible to observe a decrease in the shear strength as the moisture content increases. This reduction is more significant for specimens extracted from the top and middle of the culms $(25 \%-30 \%)$. Specimens extracted from the bottom of Guadua culms had a stress reduction of less than $23 \%$. A similar reduction on the maximum shear strength (nearest $30 \%$ ) was presented by Jiao et.al [30] for the evaluation of the effect of moisture content on the shear strength of Mosó bamboo culms.

Technical results proves that the sensitivity of bamboo specimens to changes in moisture change can be associated with the behavior of each of the culm components (lignin, cellulose and hemicellulose) [31]. Kojima and Yamamoto [32], showed that lignin and hemicellulose are more sensitive to moisture changes than cellulose fibers. Since the shear and compression failure of the material is controlled by the behavior of the matrix, it is expected that when the moisture content approaches the point of saturation of the fibers, the value of the strength will be affected.

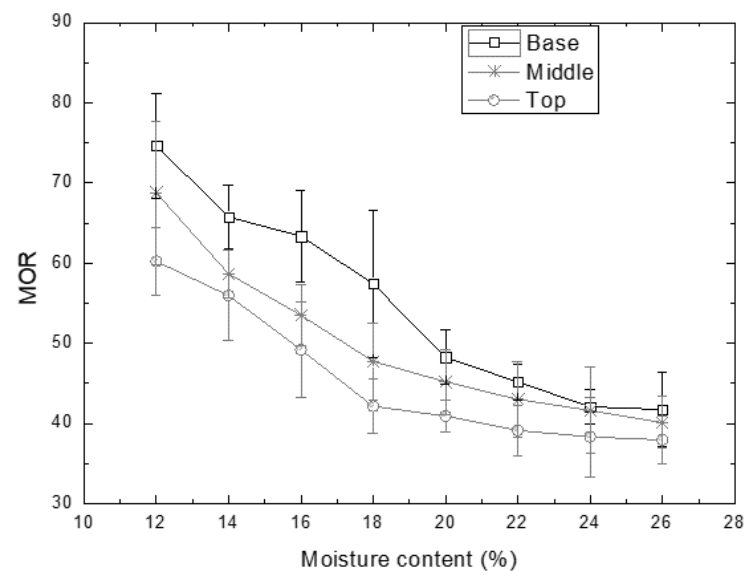

Fig. 15. Results for static bending tests. Source: Authors.
For the static bending test, center loading across a beam with a span of $300 \mathrm{~mm}$ was used (Fig. 15). Fig. 15, shows the variation of the static bending strength for specimens extracted from the top, middle and bottom of the Guadua culms. The results presented indicate a non-linear decrease in the average stress values. Depending on the region of the culms, the reduction in the value of the rupture modulus can be about $45 \%$, when the material has a moisture content close to the saturation point of the fibers. This effect can be associated to the variations that occur in the density of the material, when is exposed to humid environment for a prolonged period of time. Average values of representative points obtained during the test are shown in Table 8.

The effect of the moisture content on the MOE was calculated according eq. (8). The results are shown in Figs. 16-18. Regardless of the culm region, a MOE reduction of approximately $10 \%$ can be observed.

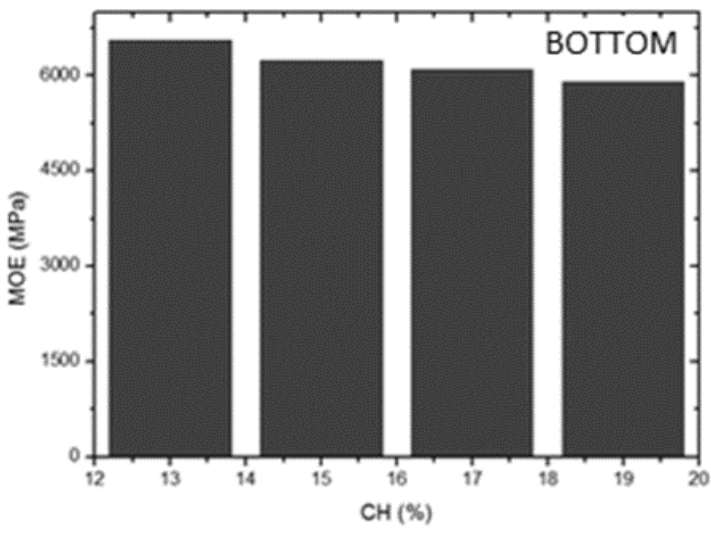

Fig. 16. Effect of moisture content on the MOE (MPa) of the bottom of Guadua culms.

Source: Authors.

Table 8. Effect of moisture Content on MOR (SD is Standard deviation in MPa)

\begin{tabular}{|c|c|c|c|c|c|c|}
\hline \multirow{2}{*}{ CH (\%) } & \multicolumn{2}{|c|}{ Base } & \multicolumn{2}{c|}{ Middle } & \multicolumn{2}{c|}{ Top } \\
\cline { 2 - 7 } & MOR (MPa) & SD (MPa) & MOR (MPa) & SD (MPa) & MOR (MPa) & SD (MPa) \\
\hline $11.00-12.99$ & 74.64 & 6.58 & 68.76 & 8.94 & 60.21 & 4.21 \\
\hline $13.00-14.99$ & 65.76 & 3.95 & 58.67 & 2.93 & 55.94 & 5.59 \\
\hline $15.00-16.99$ & 63.36 & 5.70 & 53.50 & 3.74 & 4919 & 5.90 \\
\hline $17.00-18.99$ & 57.44 & 9.19 & 47.74 & 4.77 & 42.14 & 3.37 \\
\hline $19.00-20.99$ & 48.25 & 3.38 & 45.21 & 4.07 & 40.93 & 2.05 \\
\hline $21.00-22.99$ & 45.17 & 2.26 & 43.00 & 4.73 & 39.14 & 3.13 \\
\hline $23.00-24.99$ & 42.09 & 2.10 & 41.61 & 5.41 & 38.32 & 4.98 \\
\hline
\end{tabular}

Source: Authors. 


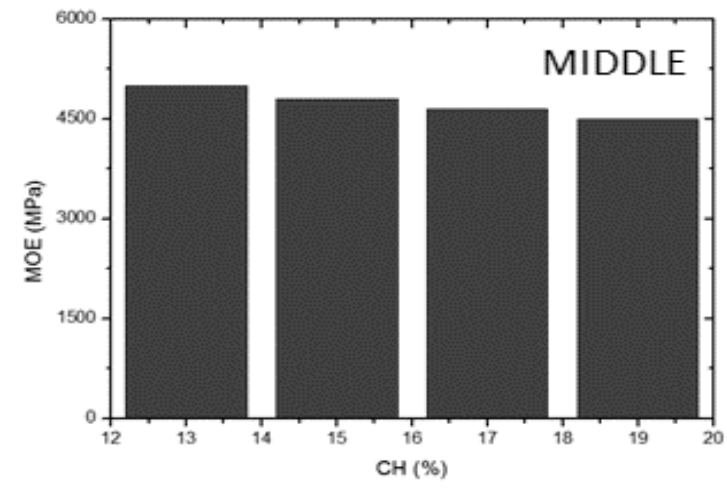

Fig. 17. Effect of moisture content in MOE (MPa) of Middle of Guadua culms. Source: Authors.

The results presented in Figs. 16-18 show that the variation in moisture content does not cause significant changes in the stiffness of the culms, when the material is subjected to static bending. Similar results was presented by Jiang et al. (a reduction of approximately of $15 \%$ ) [30]. The low sensitivity to variations in the value of the flexural modulus could be associated with the typical structure of bamboo culms, principally their cellulose content, principal responsible for the stiffness of culm in static bending test.

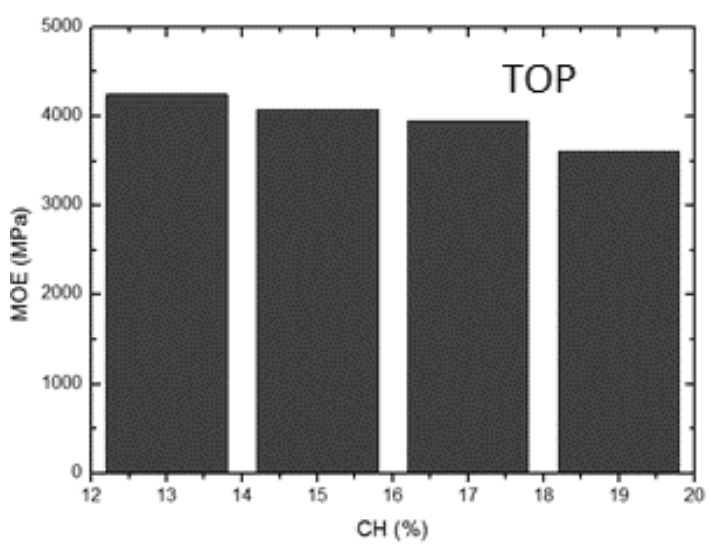

Fig. 18: Effect of moisture content in $\mathrm{MOE}$ (MPa) of Top of Guadua culms. Source: Authors

\section{Conclusions}

The influence of the moisture content on the mechanical properties of elements extracted from the bottom, middle, and top of bamboo culms was evaluated. The experimental characterization was focused on the determination of compression, bending, and shear strength.

From the results, it is possible to verify that an increase in the moisture content reduces the mechanical strength of the material. The decrease in the values of maximum stress is more significant for moisture values between $12 \%$ and the saturation point of the fibers and is accompanied by important dimensional changes that impair the mechanical performance of the material. The results show that above the point of saturation of the fibers the mechanical behavior of the culms is not modified.

\section{RECOMMENDATIONS}

It is recommended for future work to analyze the influence of moisture variation on the microstructure of Guadua elements and the development of a numerical model that can predict the behavior of bamboo elements in relation to the equilibrium humidity of the principal regions of Colombia.

\section{FINANCING}

This paper is a derivative product of the project (INVING-2389) financed by the Vice-rectory of Research of Universidad Militar Nueva Granada-validity (2017).

\section{ACKNowlegments}

Authors thank the Military University Nueva Granada that made possible the realization of this work through the research project with traceability code INV-ING-2389, validity 2017.

\section{REFERENCES}

[1] C. B. Okhio, J. E. Waning and Y. T. Mekonnen, "An Experimental Investigation of the Effects of Moisture Content on the Mechanical Properties of Bamboo and Cane," $C y$ ber Journals: Journal of Selected Areas in Bioengineering (JSAB), vol. 11, no. 1, pp.7-14, Nov. 2011.

[2] H. Chen, M. Miao and X. Ding, "Influence of moisture absorption on the interfacial strength of Bamboo and cane and Cane/vinyl ester composites," Composites Part A: Applied Science and Manufacturing, vol. 40, no. 12, pp. 2013-2019, Dec. 2019, doi: https://doi.org/10.1016/j.compositesa.2009.09.003

[3] C.C. Gerhards, "Effect of Moisture Content and Temperature on the Mechanical Properties of Wood: An Analysis of Immediate Effects," Wood Fiber Science, vol. 14, no. 1, pp.4-36, Jan. 1982.

[4] Z. Jiang, H. Wang, G. Tian, X. Liu and W. Yu, "Sensitivity of several selected mechanical properties of moso bamboo to moisture content change under the fibre saturation point," Bioresources, vol. 7, no. 4, pp. 5048-5058, Aug. 2012, doi: https://doi.org/10.15376/biores.7.4.5048-5058

[5] J. Niklewski, M. Fredriksson and T. Isaksson, "Moisture content prediction of rain-exposed wood: Test and evaluation of a simple numerical model for durability applications," Building and Environment, vol. 97, no. 1, pp. 126-136, Feb. 2016, doi: https://doi.org/10.1016/j.buildenv.2015.11.037

[6] H. Daassi-Gnaba, Y. Oussar, M. Merlan, T. Ditchi, E. Géron and S. Holé, "Wood moisture content prediction using feature selection techniques and a kernel method," Neurocomputing, vol. 237, no. 10, pp. 79-91, May. 2017, doi: https://doi.org/10.1016/j.neucom.2016.09.005

[7] T. Mai, S. Razafindratsima, Z. Mehdi, F. Demontoux and F. Bos, "Non-destructive evaluation of moisture content of wood material at GPR frequency," Construction and Building Materials, vol. 77, no. 1, pp. 213-217, Feb. 2015, doi: https://doi.org/10.1016/j.conbuildmat.2014.12.030 
[8] H. Liu, Z. Jiang, B. Fei, C. Hse and Z. Sun, "Tensile be haviour and fracture mechanism of moso bamboo (Phyllostachys pubescens)," Holzforsch, vol. 69, no. 1, pp. 47-52, May. 2015, doi: https://doi.org/10.1515/hf-2013-0220

[9] S. Askarinejad, P. Kotowski, F. Shalchy and N. Rahbar, "Effects of humidity on shear behavior of bamboo," Theoretical and Applied Mechanics Letters, vol. 5, no. 6, pp. 236-243, Nov. 2015, doi: https://doi.org/10.1016/j.taml.2015.11.007

[10] B. Sharma, A. Gatóo, M. Bock and M. Ramage, "Engineered bamboo for structural applications," Construction and Building Materials, vol. 81, no. 1, pp. 66-73, Apr. 2015 , doi: https://doi.org/10.1016/j.conbuildmat.2015.01.077

[11] T.-Y. Chen, C.-H. Shih and H.-C. Chen, "Determination of the moisture content at fiber saturation point of bamboo by nondestructive testing method with stress wave timer," in: Proc. of the fifth world conf. on timber engineering, Montreaux, Switzerland, Aug. 17-20, 1998, vol. 2, pp.820-821.

[12] M. R. Wakchaure and S. Y. Kute, "Effect of moisture content on physical and mechanical properties of bamboo," Asian Journal of Civil Eng., vol. 13, no. 6, pp.753-763, Feb. 2012.

[13] S. Nahar and M. Hasan, "Effect of chemical composition, anatomy and cell wall structure on tensile properties of bamboo fiber," Eng. Journal, vol. 17, no. 1, pp. 61-68, Jan. 2013, doi: https://doi.org/10.4186/ej.2013.17.1.61

[14] H. Wang, G. Tian, W. Li, D. Ren, X. Zhang and Y. Yu, "Sensitivity of bamboo fiber longitudinal tensile properties to moisture content variation under the fiber saturation point," Journal of Wood Science, vol. 61, no. 3, pp. 262-269, Feb. 2015, doi: https://doi.org/10.1007/s10086-015-1466-y

[15] R. R. Mvondo, M. Meukam, J. Jeong, D. D. Meneses and E. G. Nkeng, "Influence of water content on the mechanical and chemical properties of tropical wood species", Results in Physics, vol. 7, no. 1, pp. 2096-2103, Jun. 2017, doi: https://doi.org/10.1016/j.rinp.2017.06.025

[16] L. Xiaobo, "Physical, chemical, and mechanical properties of Bamboo and cane and Cane and its utilization potential for fiberboard manufacturing," M.S. Theses, Dpt. Renewable Natural Resources, Louisiana State Univ. and Agri. and Mech. College, USA, 2004. [Online]. Available: https:// digitalcommons.lsu.edu/gradschool_theses/866

[17] N. Pérez-Peña, L. Valenzuela, J. E. Diaz-Vaz and R. A Ananías, "Prediction of equilibrium moisture content in wood in relation to the specific gravity of the cell wall and environmental variables," Maderas, Ciencia y Tecnología, vol. 13 , no. 3 , pp. 253-266, Jun. 2011, doi: https://doi. org/10.4067/S0718-221X2011000300002

[18] Q. Xu, K. Harries, X. Li, Q. Liu and J. Gottron, "Mechanical properties of structural bamboo following immersion in water," Eng. Structures, vol. 81, no. 1, pp. 230-239, Dec. 2014, doi: https://doi.org/10.1016/j.engstruct.2014.09.044

[19] S. Jakovljevic, D. Lisjak, Z. Alar and F. Penava, "The influence of humidity on mechanical properties of bamboo for bicycles," Construction and Building Materials, vol. 150 no. 1, pp. 35-48, Sept. 2017, doi: https://doi.org/10.1016/j. conbuildmat.2017.05.189

[20] M. Gutiérrez-González and C. P. Takeuchi-Tam, "Efecto del contenido de humedad en la resistencia a tensión paralela a la fibra del bambú Guadua Angustifolia Kunth," Scientia et Technica, vol. 19, no. 3, pp. 245-250, Sept. 2014 doi: http://dx.doi.org/10.22517/23447214.9117

[21] J. Dumar, "Determinación de la variación de la resistencia a flexión y módulo de elasticidad longitudinal de la guadua angustifolia kunth, con el contenido de humedad," Mg. Tesis, Fac. de Ing., Univ. Nacional de Colombia, Bogotá, D.C. Colombia, 2015

[22] G. Giraldo and G. Wbeimar, "Resistencia de la sección transversal de la guadua sometida a compresión," Reporte Técnico, 2014. [Online]. Available: http://bdigital.unal. edu.co/4969/

[23] Preservación y secado del culmo de Guadua Angustifolia Kunth, NTC 5301, ICONTEC, Instituto Colombiano de Normas Técnicas, Bogotá, D.C. Colombia, Jul. 2007.
[24] Métodos de ensayo para determinar las propiedades físicas y mecánicas de la Guadua angustifolia Kunth, NTC 5525, ICONTEC, Instituto Colombiano de Normas Técnicas, Bogotá, D.C. Colombia, Sept. 2007.

[25] M. Fuentes-Salinas, "Estimación del punto de saturación de las fibras (PSF) de las Maderas," Revista Chapingo Serie Ciencia Forestales y del Ambiente, vol. 6, no. 1, pp. 79-81, Jan. 2000. Available: https://chapingo.mx/revistas/revistas/articulos/doc/rchscfaVI325.pdf

[26] M. Gutiérrez, J. I. Bonilla, M. F. Cruz and J. G. Quintero, "Linear expansion and fiber saturation point of Guadua angustifolia Kunth", Colombia Forestal, vol. 21 , no. 1, pp. 69-80, Jun. 2018, doi: https://doi. org/10.14483/2256201X.11501

[27] H. Hamdan, C. A. S. Hill, A. Zaidon, U. M. Anwar, and M. Abdel-Latif, "Equilibrium moisture content and volumetric changes of Gigantochloa Scortechinii," Journal of Tropical Forest Science, vol. 19, no. 1, pp. 18-24, Jan. 2007, Available: https://www.jstor.org/stable/43594693

[28] W. Liese and M. Köhl, (Eds), Bamboo: The Plant and its Uses (Tropical Forestry)," Switzerland: Springer, Cham, (Int. Publishing), 2015, doi: https://doi.org/10.1007/978-3319-14133-6

[29] T. Y. Lo, H. Z. Cui and H. C. Leung, "The effect of fiber density on strength capacity of bamboo," Materials Let ters, vol. 58, no. 21, pp. 2595-2598, Aug. 2004, doi: http:// doi.org/10.1016/j.matlet.2004.03.029

[30] Z. Jiang, H. Wang, G. Tian, X. Liu and W. Yu, "Sensitivity of Several Selected Mechanical Properties of Moso Bamboo to Moisture Content Change Under Fiber Saturation Point," Bioresources, vol. 7, no. 4, pp. 5048-5058, Aug. 2012, doi: http://doi.org/10.15376/biores.7.4.5048-5058

[31] J. A. Janssen, "The relationship between mechanical properties and the biological and chemical composition of bamboo," In Bamboo Production and Utilization, Higuchi, T. (ed.), Proc. of the XVII IUFRO World Cong., Kyoto, Japan, Sept. 6-17. 1981, pp- 27-32.

[32] Y. Kojima and H. Yamamoto, "Properties of the cell wall constituents in relation to the longitudinal elasticity of wood," Wood Sci. Technol., vol. 37, no. 5, pp. 427-434, Mar. 2004, doi: https://doi.org/10.1007/s00226-003-0177-5

Martha L. Sánchez graduated with a degree in civil engineering from the Instituto Superior Politécnico José Antonio Echeverría (ISPJAE), La Havana, Cuba, in 1989, the M.Sc. in civil engineering (structures) from the Pontificia Universidade Católica do Rio de Janeiro (PUC-Rio), Brazil, in 2002, and the Ph.D. in Engineering (mechanics of solids and structures) at the Instituto Tecnológico de Aeronáutica (ITA), Brazil in 2008. Currently, she is an assistant professor of the Universidad Militar Nueva Granada (UMNG), Colombia, and researcher of the Structural and Seismic research group at UMNG. https://orcid. org/0000-0002-4718-0569

Luz Yolanda Morales graduated with a degree in civil engineering from the Universidad Militar Nueva Granada (UMNG), Bogotá, Colombia in 1988, the M.Sc. in Education from the Universidad de la Sabana, Bogotá, Colombia in 1998, and the Ph.D. in Engineering Sciences at the Universidad Santiago de Chile. Santiago, Chile 2011. Currently, she is an associate professor of the Universidad Militar Nueva Granada (UMNG), Colombia, and researcher of the Engineering, Geomatics and Education research group (IGE) at UMNG. https://orcid.org/0000-00018152-5594 